\title{
Oral Literature as a Tool for Conflict Resolution
}

\author{
Uche Janet Ogbalu Ekwentị \\ Department of Igbo Language Anambra State University Uli, Igbariam Campus, Nigeria \\ Email: ouchejanet@yahoo.com
}

Received: 18 May 2019; Revised: 22 June 2019; Accepted: 2 July 2019; Published: 25 July 2019

\begin{abstract}
Oral literature is that literature that is composed and transmitted orally in face to face contact for cultural continuity, education, edification and unification. It is an essential property of non-literate community. Story telling is one of the ways through which this transmission is carried through. During this period, the ideals cherished by members of the community are interwoven into the stories. Those things that make for the unity of the community are also emphasized. The stories about their heroes and the selfless deeds of these heroes in the society are told for members of the society to emulate. These stories are sources of pride to the members of the society. It gives them collective solidarity and unity of actions. The study of oral literature as a field of learning coincided with nationalistic struggle and cultural revival in countries of Europe in the 19th century. These countries used oral literatures as a tool for conflict resolution and a means of achieving national unity. In like manner Igbo people should endeavour to channel lessons of oral literature towards resolution of conflicts amongst all sections of Igbo land. The same is true for Nigeria, which is made up of numerous divergent ethnic groups. Oral literature should be used as a means of achieving national unity by weaving into the fabrics of the stories those ideals that make for national unity. In this study the author examines ways oral literature can be used as a tool for conflict resolution.
\end{abstract}

Keywords: Oral literature, Conflict resolution

\section{Introduction}

Literature whether oral or written is all about life. It deals with lives of men and women of various ages in various societies. Literature is used as a means of educating, directing, uniting, satirizing and entertaining members of the society. Traditional society evolved literature in the form of oral literature as a result of man's desire to share his views with other members of his society to educate and direct, to entertain and to reinforce the attachment of individuals to the society. Oral literature therefore gives individual member of the society a sense of identity. It embodies the people's sympathies, emotions and moral values thereby identifying the culture of the village community and its peculiar character.

Oral literature is the expression of the rural folks consciousness in his environment. Emenyonu (1987:1) aligns that oral literature "had a definite purpose to instruct the young in the principles of right and wrong in the society". Oral literature does not instruct or educate the young alone, it also educates, unifies and inspires both older and younger members of the society. The rural communities which evolved this form of literature are generally so much endeared to it. They have used this literature for ages as a means of conflict resolution and as a means of inculcating the spirit of patriotism and nationalism amongst members of the society. Dorson, (1978:118) shows that many peoples of Europe used oral literature to achieve the unity of their country.

\section{Similarity of Oral Literature World Wide}

A careful examination of oral literature throughout the world shows that they have similar structure, similar themes and motifs, and they perform similar functions in various communities throughout the world. For example, in folktales, some of these motifs featured include; marriage motif, bareness motif, lack of male child in the home motif, maltreatment of orphan motif, famine motif, trickster motif et cetera. To portray these motifs, animals, birds, man-living things and non-living things are used as characters. They perform human actions. Though these characters perform these actions, their activities are meant for "human appreciation, evaluation, outrage, envy and education”, (Momoh, 1989:xiv). The stories in folktales mirror the activities of 
the society. The characters portrayed in folktales are representative of characters in the society. That is why the stories are powerful weapon used for the education of the members of the society. It provides emotional matrix that binds the individual with his community.

Since oral literature throughout the world perform the same functions to the community that owns it, it then follows that what causes grief to man in one part of the world will also cause grief to those in other parts of the world. Man throughout the world is appreciative; he rejoices when he is faced with good fortune or reward. Man is egalitarian in nature. He tries to maintain the spirit of egalitarianism with his fellow human being. Nature in the creation of man had put in man those instincts like instinct of curiosity, instinct of love and hatred, instinct of discrimination etc. These instincts are in man throughout the world and they account for man's similarity in behaviour throughout the world. It also account for the reason why human beings in different parts of the world evolve literature as a means of directing, educating, inspiring and entertaining his fellow human beings especially members of his society.

Another characteristic of oral literature throughout the world is the existence of heroes/heroines. These are men and women who have attained national prominence and who embody the national or the community's ideals of good behaviour. The heroes/heroines are endowed with numerous admirable qualities that are held up to the people for emulation. The achievements of are celebrated in oral literature of their various communities. In most cases some of these heroes are deified and worshipped after their death. Euhemerus in Okebalama (2003:11) observes that most of the Greek gods were men who were deified. Euhemerus maintained that Zeus one of the principal gods of the Greeks was a Cretan who traveled widely in the East and was deified there before returning to die in his native Crete.

Though Euhemerus was accused of sacrilege by his people, later, his assertion was proved to be the truth. In Okpewho (1983:2) Spencer affirms that "god Aesculapius was a deified medicine man". Deification of heroes could be seen in other parts of the world like American, Asia and Egypt. In Yoruba land (Nigeria) the Yoruba scholars support Euhemerus view. They maintain that major figures in their traditional pantheon were deified men. In Okpewho (1983:5) Babalola asserts that god Ogun was a temperamented war lord who was deified after his death. In like manner, Igbo scholars also acknowledge the existence of deified heroes in Igbo land. Afigbo, (1981:7) has it that Onoja Oboni, a warrior and one of the Abatamu of Ogurugu (Nsukka) was defied and is still worshipped in Ogurugu to this present day. In the same manner, Okebalama (2003:11) asserts that in Nsude (Udi), their hero, a renown wrestler, Uto Nsude was deified and worshipped and his deeds were celebrated in Nsude even to this present time.

Deification is the highest honour that can be accorded to the hero. It is so because from that period of deification, the hero is elevated to supernatural figure. He is then adored and respected by the people. Later, when the generation that deified the hero die off, the succeeding generation then worship him as a god and will never forgive anybody that refers to their god as a human being. Bamidele (2003:180) says:

Experience has shown that the folk mind does not take the name of Sango or Ogun in vain since

he cannot take a risk with his level of belief... in gods. I submit that the folk mind believes in the

god as a guardian of the public conscience in redressing justice and truth.

The spirit of respect adoration and implicit faith in the powers of gods in the determination of human destiny is universal throughout the world and this belief unifies the adherents throughout the world. It unifies the confidence of the people that own the particular god. In Igbo traditional society, Ogbalu (n.d. 52) comments:

\section{Each village or town regards the (god) idols as its own... Gods on the whole are supposed to have powers mostly over their town's people and their descendants in other towns... powerful gods are feared in their areas of influence which might cover several towns.}

The stories about these heroes or legends perform functions for the community that owns them. Firstly they give members of the community a collective solidarity by linking their past with the present and enabling members of the society identify their aspiration with these dead heroes. Secondly, it provides basis for conflict resolution within the social system, for the actions of these heroes become parameter through which present action can be judged. For example, the story of Sunjata legend in Okpewho (1983:24) gives a sense of togetherness, homogeneity and cohesion to all Mandinka people of Western Sudan. The choice of folk hero by members of the community is not only seen in the past but also it is current in the present society where the spirit of community has not died. Azuonye (1984:3) supporting this view asserts:

The Igbo world before the great cultural alienation not only revered the folk hero as the epitome of the beauty of human achievement, it was also a world in which environmental beauty was invested with sacerdotal reverence. 
The selection of folk hero in the community follows the same pattern not only in Igbo traditional society but also throughout every ethnic group in Nigeria, in Africa and in every part of the world in general. The folk hero is selfless in his service to his people. He suffers or even dies in pursuit of common good.

Opata (1989:38) asserts that; "The world of literature is a world devoid of impossibilities". This means that in appreciation of works of literature in general, a willing suspension of disbelief is required on the part of the appreciator. In Igbo folktales for example, spirit can transform itself to human being. Paupa "mkpụlụmkpụ” can even borrow hands, legs head et cetera and transform to human being. He can equally change to fly, bird, dog, lion and so on. This phenomenon is called "ehihi" in Igbo and usually for punitive measure. This transformation exists in most of other ethnic groups in Nigeria. There is another category of this transformation which is on healthy ground. The hero may transform to another type of creature in his effort to save his people. Supporting this view, Ngugi (1985:68) referring to Jomo Kenyatta, during Kenya's struggle for independence says; "Dedan can change himself into anything - a white man, a bird or a tree. He can also turn himself into an aeroplane. He learnt all this in the Big War”.

In the same manner, during Nigeria's struggle for independence, similar tales exist around Nnamdi Azikiwe. Some tales narrated about him by the folks say that during his struggle to free his people (Nigeria) from European rule, the Europeans see him as an intelligent man and therefore want to kill him. One old woman prepares a potent medicine for him and with that medicine, Zik can change to anything he likes. In some occasions, he changes to an old man with a walking stick and passes through their road block they mounted to catch him. Because of constant problems the Europeans are having from Zik, they decided to grant independence to Nigeria. Zik was said to be holding the key to Bar Beach in Lagos. He locked the beach so that its water would not overflow its bank and harm Nigerians.

This type of story is invented by the folks about their hero to win public admiration for the hero. The folks tell these stories with pride and respect for the hero. The story of Zik and Jomo caught across ethnic boundary in their respective country. One can rightly asserts that they are symbol of their national unity. Azuonye (1984:2) asserts:

The folklore hero is an ever resent reality in every society in which the spirit of community has not died. The capacity to project the heroic image in the contemporary leader is a powerful cultural indicator of social vitality.

The folk hero is revered in every community. They are respected and the people aspire to emulate their deeds.

Among the warlike Igbo community of Ohofia in Cross River State of Nigeria, there exists powerful historical heroic epic. This epic portrays the views and aspirations of the warlike community. As a warlike community, they cherish valour, men who are not afraid of blood. They cherish and honour people would bring as many human heads as possible to the community. On the other hand, weak men are insulted and neglected. They have no respect, they are called 'ụjọ’ or cowards. In such community, stories portraying men and women of valour, men and women who bravely fought the war and brought in human heads are told to inspire the members. The members of the community look on these heroes with admiration and pride and imitate them in their actions.

One of such stories told by the natives is the story of Nne Mgbafọ. According to this story, Nne Mgbafọ is a woman who behaved very much like a man. After the death of her first husband in Arọchukwu, she sets out to find new husband. She searches in many communities and fails. At last she meets Uduma, a native of NdeAna m-Ele-m-Ulu-Uma. She marries him. Uduma was a dishonourable coward “onye ujjọ”. He had not yet fulfilled his manhood responsibility as required by the heroic ethos of his age by winning a human head in battle. Nne Mgbafọ cooks a special meal for her husband and urges him to go to war which had just broken out on Ibibio land. Uduma goes to war but is slain in the battle. When the news of his death reaches Nne Mgbafọ, she immediately approaches the people of Ama Achara, the people that took the head in the battle and they provide her with escorts to the battle ground where she discovers the beheaded body of her husband in a heap of slain worriers. She dutifully buries the corpse under a tree and sacrifices a goat on the grave. Three market weeks after returning from this expedition, Nne Mgbafọ assails and over powers a young man who she finds wandering alone at Usukoam. She chops off his head and buries his body in her husband's grave as a befitting sacrifice.

This type of tale is told in this war like community to stress the importance of brevity and determination in fighting war. The virtues Nne Mgbafọ are cherished by members of the society. By eulogizing Nne Mgbafọ in this manner, the Ohofia society holds her up as a model that should be imitated by its citizens. 
Again, romantics epic otherwise known as "ịta" by the people exists among the fishing and agricultural communities of Nando, Aguleri, Nzam, Nteje etc of Anambra State. Amongst such tales is the story of their hero, Ameke Okoye who was the grandson of a powerful witch called Emebolu - meaning, revenge. She acts as the hero's supernatural props. His mother's name was Mbaago. Ameke was born after a long period of barrenness on the side of his mother. His birth takes place in an extraordinary circumstance after an extraordinary gestation period of thirty nine years. At birth, he is a fully mature person and he is so huge that it requires the collaboration of the entire population of his home town Adaja to feed him. He drinks directly from rivers and lakes and often he drains the whole source dry in one sip. Ameke soon grew very strong surpassing his age mates. He engages and overcomes a succession of monsters that trouble his people and destroying their farm lands. He had twenty encounters with these monsters which he defeated.

In the last of these encounters which takes place after Ameke had completed his mission on earth, he dies while being swallowed up by Ịkakpụlụenyinisi who also dies in the struggle. Their death was because their metaphysical props from both sides deserted each of them. Ameke was half swallowed by the monster and half of him remains outside his mouth when he also dies. His grandmother, Emembọlu also dies at the same time his grandson dies.

Many of these "ịta" or Romantic Epics are told during the period Omambara River overflows its bank. At this period many fishes were caught. The telling of these tales keeps the fishermen awake throughout the night. As an epic story, it takes several nights to complete the story. Again during festivals in this area, minstrels compete on these tales and the winner is rewarded. These stories bind members of the community and it is a source of pride to them. It is also a form of entertainment to them and they look up to these heroes as their models.

The story of Ozidi Saga by J. P. Clark is another example of such epic. The story is from Ijọ community in Niger Delta. Ozidi was a post humously born hero who avenges the assassination of his father by fellow warriors. He never stops his slaughter until he eliminates all his enemies in his community and reigns in an uncontested supremacy.

In West Africa and in Nigeria in particular, cultural continuity within non-literate traditional societies is largely carried out through oral transmission. All beliefs, all values and all forms of knowledge are communicated between individuals in face to face contact and they are stored only in human memory. In traditional African communities, story telling provides entertainment, moral instruction and an opportunity to express solidarity. There are different types of traditional stories with varying contents, patterns of narrations and significance.

Legends perform a dual function for the community that possesses them, first they give the members of the community a collective solidarity by linking their past with the present by enabling the living members of the community identify themselves and their aspirations with those of their ancestors. Legends and pseudo history provide the legalistic basis for settling problems or rights and obligations within the social system, for the doing of the traditional heroes become precedent and norms by which present action can be judged.

Possession of myths is also one of the characteristics of oral literature throughout the world. These myths are also regarded as true in the community where they originate, they also have pseudo-religious significance. They give meaning to the mysteries of existence and cosmic order. Without myths traditional society would lose their rationale and the confidence that hold it together.

\section{Significance of Performance in Oral Literature}

Finnegan (1970:92) notes that there are existence of bards or court poets amongst people of Yoruba, Hausa and some other African communities. Their functions seem to derive from the picture of the rhapsodist Homeric age. The bard is depicted as standing before the gathered lords to chant the heroic lays handed down through generations. These heroic deeds of the ancestors are found in Europe, Africa and in other continents. In Igbo land and in Nigeria in general, these stories generate pride amongst the rulers and his people in the achievement of his ancestors and inspire him to achieve further than his predecessors. Okpewho (1990:7) has it thus:

In my fieldwork among Aniocha, story tellers in Bendel State, Nigeria, I encountered one who acclaimed that his box hap had a spiritual origin. In my reading of the Sunjata story collected from Gambia Mandinka, I find a narrator who claims his guitar has a spiritual origin. In my reading of ancient Greek heroic narratives, I find Hesiod claiming that the muses gave him a wand for use in singing heroic song. 
From the extract above, one concludes that one of the reasons why the bards, the minstrels or the performers are held in high esteem in the community is because the members of the community believe that the message they are relaying is divine. Since their appointment is not from human but from the gods, the members of the public is bound to accept the message as true. In the performance, the bard takes time to recount the history of the names of kings of the land and their achievements. The bard is honest, trust worthy and of moral distinction. It is the praise names above all else which elevate his story. It is the repetition of some of the key words to emphasize the deeds that strive the blood and makes the listeners swell with pride.

Songs are also used to satirize those who deviate from the acceptable ways of the society. For example, a girl who indulges in a pre-marital sex and becomes pregnant is satirized, a man who beats up his wife, wife who cooks late in the night etc are satirized. Example:

O o Nwakaego-o-o-ewu!
O o Nwakaego---o-o-ewu!
Nwakaego, you drank hot pap
It swells your stomach
You shouted okokoko
It is not good.
$i$ sawanje... i sawanje
why are you shouting
when you were enjoying it
did you tell us and
now you are shouting
it is not good.
$i$ sawanje, $i$ sawanje $-e$

From the extract above, one can discern that the song mocks Nwakaego the wayward girl who imagines that she is the most beautiful in the community. The song implies that it is her socially repulsive way of life that results in her unwanted pregnancy. From this satire, no one in the village is expected to emulate Nwakaego's character.

The exercise above shoes that oral poetry is used in traditional Igbo societies and also in Nigeria as a medium for inculcating socially acceptable behaviours and in criticizing socially disapproved behaviours in the society.

Story telling is one of the ways through which oral literature of the people is handed down from one generation to the other. The telling of these stories normally takes place in the evenings after the evening chores. Members of the family and their neighbours normally gather at the father's Obi or the mother's hut to hear these stories. Folktales are the main stories told at this time. In these folktales, the people's ideas, their culture, their world view and those important things that make for the unity of the people are artistically woven into these stories. Nwaozuzu (2006:2a) notes that "the idea couched in the witty narratives is based on the observation of people's beahviour and reflects the view of ordinary men and women on the conduct of life". That is why it is said that folktale mirrors the activities of members of the society. In his own opinion, Ashton (1957:20) adds that; "the introduction of folkways in folktales is merely to give verisimilitude to a depiction of life of a particular locality”.

One common characteristics of this story telling session is that the performers is able to hold his audience attention for hours without any of the party getting tired. This means that the narrator can hold his audience as long as he wishes. He is able to achieve this because story telling or performance ensures audience participation. Apronti (1978:77) advancing the reason for the success of performance in story telling says: "a literary type such as folktale owes its vitality to the fact that distinction between narrator and audience is blurred thus making audience participation a condition for successful realization of the type; story telling takes place in a free and relaxed atmosphere and the audience is free to express their views and participate freely without any hindrance. Most of these folktales are interspersed with songs. This helps to enliven the narrative. Obechina (1990:47) affirms that; "songs not only heighten the narrative but also vivify it. It also ensures audience participation”. The audience sing the chorus clap their hands or even correct the performer whenever he deviates from normal way of telling the story or in portrayal of his characters. On this audience participation, Okpewho (1990:161) adds thus: 
Because the experiences and expectations of the society are woven round the events of follitales, the suspension of disbelief by the audience is an easy one and this also account for their instant correction given to the performer when he deviates from the normal routine of the tale or normal way of telling the story.

Onyekaonwu (1986:230) observes that in oral traditional story-telling, two main aspects of performances are pursued. These are: the physical performance aspect (usually visual) and the verbal or oral performance aspect usually acoustic. This follows that the performer evokes the audience senses of sight and auditory senses for these senses play great role in the full realization of the aesthetic quality of the story being rendered.

Folktale is not only the story enjoyed at the story telling session. The audience was also entertained with such stories as - stories about their legends, gods/goddesses, history of their origin. Proverbs, riddles and other forms of arts were also used by the performer for the audience to emulate. These are essential parts of traditional lore. It is important to note that the events of folktales are introduced to traditional Igbo child and African child in general right from infancy. This means that African child is exposed to story telling and participation right from infancy. He then grows up with the lessons of these traditional lores.

Emenyonu (1987:3) affirms that; "the bond of affection between mother and child in Igbo traditional culture is a very strong one, especially when the child happens to be a son". The mother takes time to integrate her son into the culture of the society and the society's way of life with the folktales. Usually other children join the story. When the mother retires, children continue with the stories. Story telling session therefore had the following impact on traditional Igbo child:

- It gives the child the opportunity of using imagination to decipher the truth and develop his intellectual ability. Their wits are tested by allowing them give quick answers to questions posed to them in the form of riddles.

- It helps the child develop creative thinking - a natural process through which a person becomes aware of problem, difficulty or gap in an information for which he has no learned response.

- Obedience and respect are other contribution of folklore to the children development. Most stories and songs condemn bad behaviours. In African folktales. Good always triumphs over evil, truth over falsehood, honesty over dishonesty.

- National consciousnesses and patriotism are inculcated in the children with the aid of folklore. Children learn bravery selflessness etc from legendary stories and songs that tell how heroes suffered greatly or even died for their people. When traditional Igbo child or African child is inculcated with these virtues from childhood, it means that by the time he gets to adult life, these virtues had become part and parcel of his life. This accounts for the reason why both children and adult enjoy stories of folktales despite their fictional nature.

Clarke, (1976:1) comments that the earliest form of literature was a simple account of some heroic deeds recited or sung by the specially gifted individual who became known as bard or minstrel in the presence of the listening audience. These bards can be seen in the king's court or the Oba's palace entertaining the people. They recount the deeds of the kings and their consequent successions. They can be regarded as the custodian of the people's history. They also entertain people during festive occasions during which they reel out poetic praises in favour of a person and these songs are carried out in native dialects of the singes songs generate ethnic pride and gingers the spirit of nationalism and thus become weapon for conflict resolution.

Vansina (1985:34) has it that "for the narrator to achieve the experience, "he must know his audience, he must know the personalities that make up his audience, so as to arrange and select his materials in such a way to appeal to his audience and at the same time assimilate, dissolve, multiply the various characters in the tale". To Vansina, "it is the story teller's ability and style that make him master of his craft". This is sop because it is through his style of narration that he can weave into the story those ideals cherished by the society and also emphasize those things that make for the unity of the society. The bard takes time to recount the history of the names of kings of the land and their achievement without making any mistake. He sings praises to kings and heroes of the land. The praise names have an important effective function - it is the praise names above all else which elevate the song from mere recital of event to that stirs the blood and makes the listeners swell with pride. The bard uses formulae and the recitation mode to elevate his performance. Bards are always honest, trustworthy and of moral distinction. They are so much attached to their native villages. They are so much attached, Nwahunanya advancing (1998:89) aligns that: 
The oral literary artist in such societies was vested with enormous social responsibilities, especially with regard to his position as an entertainer and regulator of social behaviour. He was an important as one of the society's mechanisms for social control through the se into which he puts his lyrics, poems, stories and the music which accompany them.

The performer is an entertainer, a social critic, an educator and a custodian of the people's history and so he is always very close to his people so he is always very close to his people.

\section{Oral Literature, a Tool for Conflict Resolution}

The study of oral literature as a field of started in $19^{\text {th }}$ century, that coincided with the nationalistic struggles and cultural revival amongst various countries of Europe. From Dorson (1963:18) many countries of Europe resorted to oral literature of their people as a means of achieving their national unity and as a weapon for their conflict resolution amongst various sections of its people. In Germany for example, Jacob and Weilhelm Grimm, otherwise known as Grimm brothers published influential volumes of folk narratives and their interpretations of Germanic mythology and with these they achieved Germanic unity. In Ireland folklore was used as stimulus to imaginative research and a source of national pride through folklore was entwined with political ideology and virulent nationalism.

In Soviet Russia, oral literature was used as a powerful weapon to advance communism. Oral literature served not only the socialist but also served the nationalist cause by welding the diverse people of Soviet Union into one closer unity based on common workers lore. In Japan folklore was used to recapitulate the ancient Japanese animistic religion. Dorson (1978:118) asserts that the Jewish folktale narrators careful description of their lives in Europe - their struggles and their sufferings enlightened the younger generations. These stories are source of inspiration and source of their unity.

It will be recalled that oral literature is totally composed by the folks. Oral literature embodies their do's and don'ts what they cherish and what they despise their total ways of life. The countries that had used oral literature for unification of their state had first of all studied the character of the folks and learnt how they operate through that way they were able to succeed in achieving their national unity.

From the study so far, it can be seen that oral literature throughout the world has identical characteristics, identical structure, identical themes and motif and they serve the same purpose. Different countries of the world have used oral literature as a tool for their conflict resolution and national unity. In like manner, in Nigerian, during the colonial period, oral literature provided an avenue for the unity of the country. The story circulating around the legendary Zik of Africa during the struggle for Nigerian independence unifies various ethnic groups in the country. In like manner, the stories circulating round Jomo Kenyatta of Kenya during the country's struggle for independence provides avenue for the country's unity for every member of these country aspire to be like these heroes.

Nigeria is made up of diverse ethnic groups currently if Nigeria each of these ethnic groups is struggling towards emancipation of the group. As a result there is more of ethnic consciousness rather than national consciousness. If this type of attitude is allowed to continue, Nigeria as a nation will face disintegration. Nigerian leaders should therefore borrow a leaf from other countries of the world that had used oral literature as a tool for their conflict resolution and a tool for the achievement of their national unity. Oral poetry or songs offer a lot of folkloristic elements. These elements range from the mythical to historical bards can also recapture real happening in the society. We have also seen that the success of the performance rests on the capability of the bard to sustain the interest of his audience to the end. These bards and minstrels can be employed by the leaders of the country to entertain the audience during which they infuse those ideals cherished by the country. They also emphasize those elements that make for national unity. Political ideology can be infused in the songs thus providing common front for the achievement of national unity.

Folks in general are innocent in their dealings. They acknowledge the spirit of patriotism and selfless deeds of their heroes. This accounts for reason why they use oral literature as a means of achieving their community's unity. They generate consciousness or spirit of patriotism through the use of oral literature. In Nigeria, about seventy percent of its population is still illiterate. Oral literature is a strong weapon to be used for conflict resolution and for achievement of national unity. This means that folktales, myths and legends and other forms oral literature can be used for conflict resolution since these stories binds members of the community by emphasizing in these stories those elements that make for national unity and those deals cherished by the country. Oral literature has been used traditionally in creating national character models that appeal to entire population. This is possible because oral literature presents its propaganda in the guise of aesthetically appealing narratives. 
One outstanding quality of oral literature is its flexibility. This means that the narrator can add or subtract story from its original trend. He can add elements into the story to suite his desire. This means that the leaders of Nigeria can add those things make for national unity into their narratives.

In modern Nigeria, there is a pressing need to generate national consciousness and the national unity amongst the entire population of the country. This could be done by emphasizing the things that hold together various ethnic nationalities that comprise i.e. Nigerian State. Another way of achieving this is by mobilizing the teaming masses of this country and engendering in them the patriotic ideals that make the country strong. If the leaders of Nigeria want to build a strong united Nigeria, then they have to adopt the time tested methods of conflict resolution through the use of oral literature and through this the unity of the country is assured.

\section{Conclusion}

From the discussions so far, one can see that oral literature plays active role in the unification of the communities that own them. This is because oral literature is their own creation. It is created out of what they desire and what they despise. Nigeria is made up of diverse ethnic groups and these ethnic groups have their own oral literature. These oral literatures have similar characteristics and so the leaders of Nigeria should use them to achieve national unity just as the folks are using them.

\section{References}

Afigbo, A. (1981). Ropes of Sand. Nsukka: University of Nigeria Press.

Apronti, E. O. in Nwoga, D. (1978). Literature and Modern West African Culture. Benin: Ethiope Press.

Ashton, J. N. (1957). Folklore in the Elizabethan England. Bloomington: Indiana University Press.

Azuonye, C. (1984). Romantic Epic of Anambra Igbo. U̦wa Ndị Igbo. Journal of Igbo Life and Culture. Okike Arts Centre, 1

Bamidele, L. in Wole Ogundele et al (ed) (2003). Iba, Assays on African Literature in Honour of Oyin Ogunba. Ile-Ife: Obafemi Awolowo University Press.

Clarke, W. (1975). A Short History of English Literature. Ibadan: Evans Books.

Dorson, R. M. (1963). Introduction, Concepts of Folklore and Life Studies. Chicago: University of Chicago Press.

Dorson, R. M. (1978). Folklore in the Modern World. Hague: Mauton Publishers.

Egudu, R. (1981). The Study of Poetry. London: Oxford University Press.

Emenyonu, E. (1987). Rise of Igbo Novels. Ibadan: University Press.

Finnegan, R. (1970). Oral Literature in Africa. Oxford: The Claredon Press.

Momoh, T. (1989). Key Note Address in Emenyonu, E. (1989). Literature and National Consciousness. Ibadan: Heinemann.

Ngugi, J. (1975). Weep Not Child. Ibadan: Heinemann.

Nwahunanya, C. (1998). Theory, History and Criticism. Owerri: Corporate Impression.

Nwaozuzu, G. I. (2006), The Child as an Image of Innocence and Credulity in Igbo Folktales. Journal of Igbo Studies Association. Nsukka: Ifedimma Comm, 1

Obiechina, E. N. (1990). Language and Theme. Washington D.C.: Howard University Press.

Ogbalu, F. C. (n.d.). Igbo Institution. Onitsha: Versity Press.

Ogunde, H. in Ogunbiyi, Y. (1981) Drama and Theatre in Nigeria: A Critical Source Book. Britain: Pitman’s Press.

Okebalam, C. N. (2003). Mkpọlite Agụmaụọnụ Igbo. Enugu: Snaap Press.

Okpewho, (1979). Epic in Africa. New York: Columbia University.

Okpewho, (1990). Oral Performance in Africa. Ibadan: Spectrum Books. 